\section{In Vitro Culture of Heuchera villosa 'Caramel'}

\author{
Hua Q. Zhao, Qing H. He, Li L. Song', Mei F. Hou, and Zhi G. Zhang \\ School of Ecological Technology and Engineering, Shanghai Institute of \\ Technology, Shanghai 201418, P.R. China
}

Additional index words. callus, differentiation, shoot regeneration, rooting, acclimatization, hyperhydricity

\begin{abstract}
The procedure for Heuchera villosa 'Caramel' propagation was investigated, which involves shoot regeneration, rooting of regenerated shoots, and acclimation of regenerated plantlets. Petioles, as explants, were cultured on MS medium supplemented with 1-naphthylacetic acid (NAA), benzylaminopurine (BA), thidiazuron (TDZ) and callus formed on all media. Shoots were observed to proliferate from callus on media with BA and NAA, whereas no shoots regenerated on media with TDZ and NAA. On media containing 0.5 or $1.0 \mathrm{mg} \cdot \mathrm{L}^{-1} \mathrm{BA}$ in combination with $\mathrm{NAA}$, the regenerated shoots showed severe hyperhydricity, whereas on media containing $0.1 \mathrm{mg} \cdot \mathrm{L}^{-1} \mathrm{BA}$ in combination with NAA, the regenerated shoots grew normally. The highest shoot induction rate, $90.6 \%$, was obtained on media containing $0.1 \mathrm{mg} \cdot \mathrm{L}^{-1} \mathrm{BA}$ and 0.01 mg. $\mathrm{L}^{-1}$ NAA. The effects of indole-3-acetic acid (IAA), indole-3-butyric acid (IBA), and NAA on rooting of $H$. villosa 'Caramel' was explored. The highest rooting rate $(95 \%)$ was obtained on $1 / 2 \mathrm{MS}$ medium containing $0.2 \mathrm{mg} \cdot \mathrm{L}^{-1} \mathrm{NAA}$. In the subsequent acclimation experiments, about $85 \%$ of rooted plantlets survived and grew normally.
\end{abstract}

Heuchera villosa 'Caramel', which is native to Mexico, is a perennial of the genus Heuchera in Saxifragaceae (Hosoki and Kajino, 2003). Because of its bright and color-changing leaves, cold resistence, and shade tolerance, H. villosa 'Caramel' has been widely used as groundcovers under forests. Heuchera villosa 'Caramel' can reproduce by seeds, but the germination is slow and irregular. Vegetative propagation is commonly used, but frequently leads to variety degeneration and low survival rate. For these reasons, the large-scale production of $H$. villosa 'Caramel' is limited.

In vitro propagation approach has contributed significantly to the large-scale plant multiplication (Li et al., 2016; Papafotiou and Martini, 2016; Rout et al., 2006). Although in vitro propagation of Heuchera is still comparatively rare, micropropagation of Heuchera sanguinea Engelm. has been reported (Hosoki and Kajino, 2003; Miura et al., 1995; Stapfer and Heuser, 1986).

Received for publication 7 Sept. 2016. Accepted for publication $12 \mathrm{Jan} .2017$.

This research was supported by Base Construction Program of Shanghai Institute of Technology: Breeding of new variety and High-yield Cultivation Technique of Fragrant Plants; and Alliance Plan of Shanghai Promotion Association of Science and Technology Achievements: Breeding of new variety and seedling propagation of colored leaf ground cover Heuchera in Shanghai; and Prompting Agricultural Development on Science and Technology Program of Shanghai Municipal Government Agriculture Commission: Study on breeding of new variety and seedling propagation of Hemerocallis.

${ }^{1}$ Corresponding author. E-mail: songLL713@163. com.
Primarily, Stapfer and Heuser (1986) reported micropropagation of $H$. sanguinea by shoot tip culture on woody plant medium supplemented with $16 \mathrm{~mm}$ BA or kinetin. Then, Miura et al. (1995) succeeded in adventitious shoots induction by mature leaves and petioles of $H$. sanguinea culture on modified MS medium. The optimum hormonal concentrations were 0.19 or $1.9 \mathrm{~mm}$ NAA plus $4.4 \mathrm{~mm}$ BA for leaves and $0.19 \mathrm{~mm}$ NAA plus $0.44 \mathrm{~mm}$ or $4.4 \mathrm{~mm}$ BA for petioles. The percentage of regenerated shoots was $50 \%$ and $80 \%$ for leaf and petiole explants, respectively. Afterward, Hosoki and Kajino (2003) also reported successful shoot regeneration from petioles, leaves, and petioles with leaves on the same media as that used by Miura et al. (1995). But petioles or petioles with leaves regenerated more shoots than leaves alone. The highest regenerating rate was $60 \%$ in petiole cultures.

So in $H$. sanguinea, the regeneration rate was lowest in leaf cultures and highest in petioles (Hosoki and Kajino, 2003; Miura et al., 1995), suggesting petioles might be the optimum explants for shoot regeneration of Heuchera. Thus, in our experiments, petioles from the plants of $H$. villosa 'Caramel' were used as explants.

The objective of the study was to evaluate the effect of different growth regulators on in vitro propagation of $H$. villosa 'Caramel'.

\section{Materials and Methods}

Plant material. Petioles from the plants of $H$. villosa 'Caramel' were harvested and rinsed in running water for $1 \mathrm{~h}$ and then surface-sterilized in $75 \%$ ethanol for $15 \mathrm{~s}$ followed by being rinsed three times with sterile water. The explants were then sterilized in $0.2 \%$ sodium hypochlorite containing
$0.1 \%$ Tween $20(\mathrm{v} / \mathrm{v})$ for $7 \mathrm{~min}$. This was followed by rinsing five times with sterile water. The sterilized petioles were cut into sections $0.5 \mathrm{~cm}$ long.

Callus induction and shoot regeneration. The sterilized petioles were cultured on MS basal medium supplemented with different concentrations of NAA $(0,0.01,0.03$, and $\left.0.05 \mathrm{mg} \cdot \mathrm{L}^{-1}\right)$, BA $\left(0,0.1,0.5\right.$, and $\left.1.0 \mathrm{mg} \cdot \mathrm{L}^{-1}\right)$, and TDZ $\left(0,0.1,0.5\right.$, and $\left.1.0 \mathrm{mg} \cdot \mathrm{L}^{-1}\right)$ in separate experiments. The $\mathrm{pH}$ of the all media was adjusted to $5.8 \pm 0.1$ before autoclaving at $121{ }^{\circ} \mathrm{C}$ for $20 \mathrm{~min}$. On an average, 10 explants were placed on each bottle containing culture medium. The cultures were incubated in a growth room maintained at a light intensity of $40 \mu \mathrm{mol} \mathrm{m} \mathrm{m}^{-2} \mathrm{~s}^{-1}$ under 16 -h light $/ 8$-h dark photoperiod at $25 \pm 2{ }^{\circ} \mathrm{C}$. The explants were subcultured every 3 weeks. Callus formation frequency (explants with callus/number of explants cultured $\times 100$ ), shoot regeneration frequency (explants with shoots/number of explants cultured $\times 100$ ), and hyperhydricity frequency (explants with hyperhydric shoots/ number of explants cultured $\times 100)$ were recorded after 6 weeks of culture.

Rooting and acclimatization. For rooting, each shoot was cultured on $1 / 2$ MS basal medium supplemented with $0,0.2,0.5$, or $0.8 \mathrm{mg} \cdot \mathrm{L}^{-1}$ IAA, IBA, or NAA. The culture conditions were similar to those used for regeneration of shoots. Each treatment was repeated three times and each replicate consisted of at least 100 shoots, and rooting frequency $(\%)$ was recorded after $25 \mathrm{~d}$. The rooted plantlets were transplanted into the substrate (peat soil:perlite $=2: 1$ ), maintained in greenhouse for 2 weeks and then transferred to the open field.

Statistical analysis. Analysis of variance was performed by the statistical software SPSS19. The means were compared using Duncan's multiple range test at the 5\% level.

\section{Results and Discussion}

Callus induction and shoot regeneration. Greenish callus formation (Fig. 1A) was observed in media added with all combinations of growth regulators, ranging from $64.1 \%$ (in media added with $0.05 \mathrm{mg} \cdot \mathrm{L}^{-1}$ of NAA and $0.5 \mathrm{mg} \cdot \mathrm{L}^{-1}$ of TDZ) to $92.5 \%$ (in media added with $0.01 \mathrm{mg} \cdot \mathrm{L}^{-1}$ of NAA and $0.1 \mathrm{mg} \cdot \mathrm{L}^{-1}$ of BA) (Table 1). During subculture on the same medium for callus induction, shoots were observed to proliferate from callus. Shoot regeneration rate was above $60 \%$ on all media with combinations of BA and NAA. The highest shoot induction rate, $90.6 \%$, was obtained on media containing $0.1 \mathrm{mg} \cdot \mathrm{L}^{-1} \mathrm{BA}$ and $0.01 \mathrm{mg} \cdot \mathrm{L}^{-1} \mathrm{NAA}$. In previous works on $H$. sanguinea (Hosoki and Kajino, 2003; Miura et al., 1995), shoots also regenerated successfully on media with BA and NAA in spite of different concentrations of NAA and BA, suggesting the concentrations of growth regulators vary depending on cultivar.

Callus was also induced on all media with TDZ $\left(0.1\right.$ or 0.5 or $\left.1.0 \mathrm{mg} \cdot \mathrm{L}^{-1}\right)$ and NAA $\left(0.01\right.$ or 0.03 or $\left.0.05 \mathrm{mg} \cdot \mathrm{L}^{-1}\right)$ (Table 1$)$. But there were no shoots regenerated on all media 

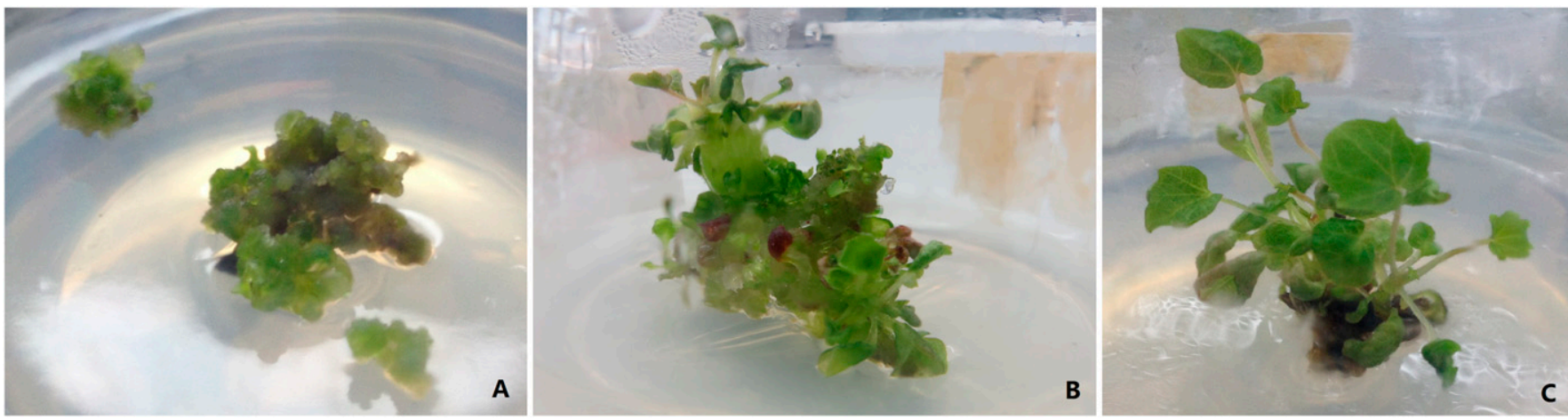

Fig. 1. Callus development, adventitious shoot development on media with different plant growth regulators. (A) Callus formation on media with $0.1 \mathrm{mg}$. $\mathrm{L}^{-1}$ benzylaminopurine (BA) and $0.01 \mathrm{mg} \cdot \mathrm{L}^{-1}$ 1-naphthylacetic acid (NAA). (B) The hyperhydric shoots differentiated on medium with $1.0 \mathrm{mg} \cdot \mathrm{L}^{-1} \mathrm{BA}$ and $0.05 \mathrm{mg} \cdot \mathrm{L}^{-1} \mathrm{NAA}$. (C) The normal shoots differentiated on medium with $0.1 \mathrm{mg} \cdot \mathrm{L}^{-1} \mathrm{BA}$ and $0.01 \mathrm{mg} \cdot \mathrm{L}^{-1} \mathrm{NAA}$.

Table 1. Effect of NAA, BA, and TDZ on callus formation and shoot regeneration in Heuchera villosa 'Caramel' in vitro.

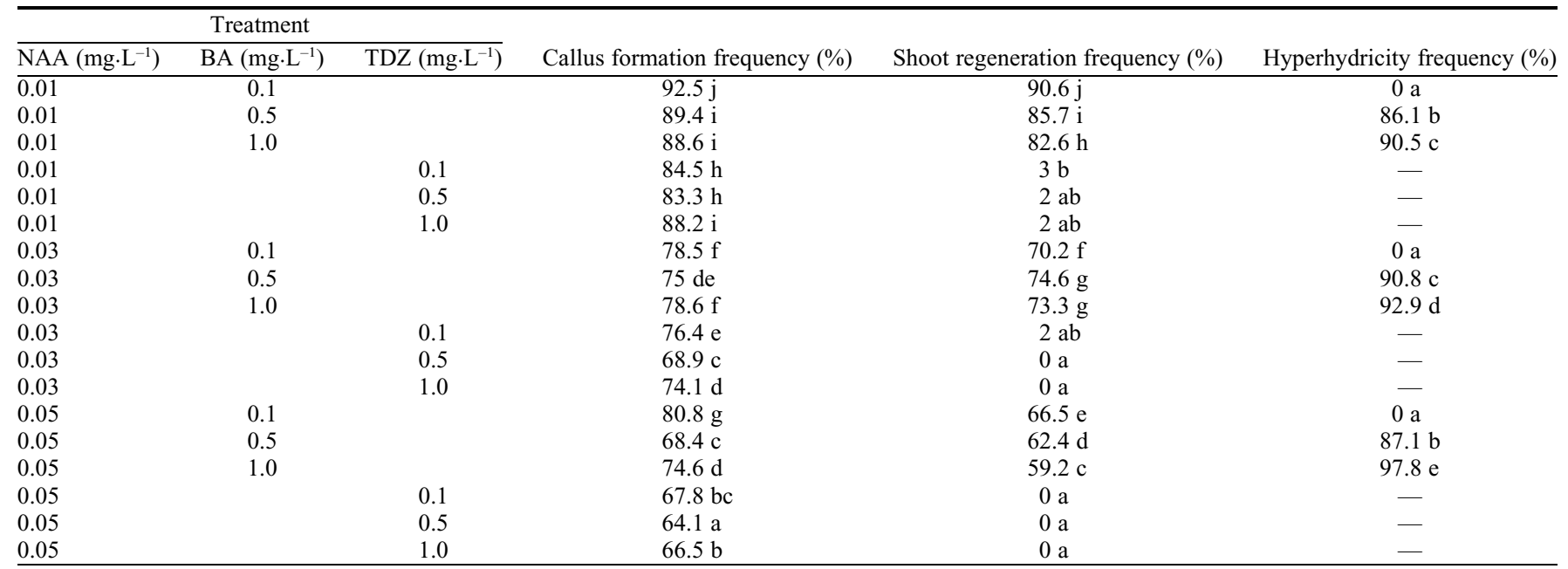

NAA $=$ 1-naphthylacetic acid; IBA $=$ indole-3-butyric acid; TDZ $=$ thidiazuron.

Different letters mean significantly different at the 0.05 level.

with TDZ and NAA (Table 1). In plant tissue culture, cytokinins are involved in growth regulation by promoting cell division, direct shoot initiation, and multiplication (Van Staden et al., 2008). Chemically, cytokinins are classified into two major groups: synthetic phenylurea derivatives, such as TDZ, and naturally occurring adenine derivatives, such as kinetin and BA. Synthetic phenylurea derivatives, especially TDZ, have been reported to be more effective for shoot regeneration and proliferation compared with BA, particularly in woody specie (Lane et al., 1998; Murthy et al., 1998; Shen et al., 2010; Tian et al., 2010). But in some cases, TDZ is not always superior. For example, in castor, BA was found superior to TDZ for obtaining the highest number of shoots from the shoot apex (Sujatha and Reddy, 1998). So the effectiveness of TDZ varies depending on cultivar. Our results showed that shoot regeneration was observed on media with all combinations of BA and NAA, whereas no shoot regeneration on media with all combinations of TDZ and NAA, which agrees with the results of $H$. sanguinea (Hosoki and Kajino, 2003; Miura et al., 1995), demonstrating that BA might be more suitable for shoot proliferation of Heuchera than TDZ.
The regenerated shoots cultured on media containing $0.1 \mathrm{mg} \cdot \mathrm{L}^{-1} \mathrm{BA}$ and 0.01 or 0.03 or $0.05 \mathrm{mg} \cdot \mathrm{L}^{-1} \mathrm{NAA}$ grew normally with normal morphological character (Fig. 1C). However, on media containing 0.5 or $1.0 \mathrm{mg} \cdot \mathrm{L}^{-1} \mathrm{BA}$ and 0.01 or 0.03 or $0.05 \mathrm{mg} \cdot \mathrm{L}^{-1} \mathrm{NAA}$, the regenerated shoots showed severe hyperhydricity, which is characterized by turgid, wrinkled, fragile, translucent, and less green (Fig. 1B).

Hyperhydricity is a morphological, anatomical, and physiological disorder, which has been reported in many species (Barakat and ElSammak, 2011; Sen and Alikamanoglu, 2013; Tabart et al., 2015; Vinoth and Ravindhran, 2015). Exogenous cytokinins were found to induce and promote hyperhydricity (Frick, 1991; Picoli et al., 2001; Vasudevan and Van Staden, 2011). Some works supported that the percentage of hyperhydric cultures and the intensity of hyperhydricity depended on cytokinin concentration (Mazri, 2015). In the work on date palm, it was found that the shoot multiplication rate increased with increasing BAP concentration, but more hyperhydricity was observed (Mazri, 2015). Another work on anchote also indicated that hyperhydric shoots were observed on media supplemented with high concentrations of BAP and kinetin
Table 2. Effect of NAA, IBA, and IAA on rooting of regenerated shoots of Heuchera villosa 'Caramel'.

\begin{tabular}{lcc}
\hline Auxins & Concn $\left(\mathrm{mg} \cdot \mathrm{L}^{-1}\right)$ & Rooting frequency $(\%)$ \\
\hline Control & 0 & $7.8 \mathrm{a}$ \\
IAA & 0.2 & $54.8 \mathrm{e}$ \\
& 0.5 & $45.4 \mathrm{c}$ \\
& 0.8 & $38.5 \mathrm{~b}$ \\
IBA & 0.2 & $47.6 \mathrm{c}$ \\
& 0.5 & $51.9 \mathrm{~d}$ \\
& 0.8 & $61.2 \mathrm{f}$ \\
NAA & 0.2 & $97.8 \mathrm{~h}$ \\
& 0.5 & $77.1 \mathrm{~g}$ \\
& 0.8 & $54.5 \mathrm{e}$ \\
\hline NAA & 1 &
\end{tabular}

NAA $=$ 1-naphthylacetic acid; IBA $=$ indole-3butyric acid; indole-3-acetic acid.

Different letters mean significantly different at the 0.05 level.

(Kahia et al., 2016). Similarly, our work suggested that shoots regenerated normally on media with lower concentration of BA $(0.1$ $\left.\mathrm{mg} \cdot \mathrm{L}^{-1}\right)$, whereas hyperhydricity phenomenon appeared on media with higher concentration of BA $\left(0.1\right.$ or $\left.0.5 \mathrm{mg} \cdot \mathrm{L}^{-1}\right)$ (Fig. 1B), which was in favor of the prior conclusions.

However, other work proved that the type of cytokinin played the major role in 

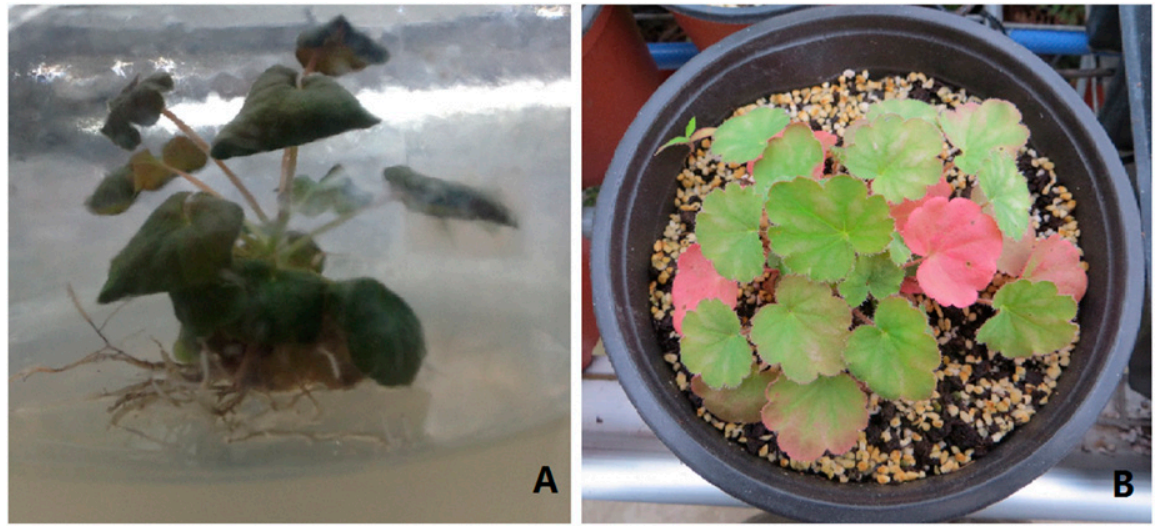

Fig. 2. Rooting and acclimation of Heuchera villosa 'Caramel' plantlets. (A) Rooting on medium with $0.2 \mathrm{mg} \cdot \mathrm{L}^{-1} 1$-naphthylacetic acid. (B) The rooted plantlets.

hyperhydricity induction, whereas the concentration has little influence (Kadota M and Niimi, 2003), in which synthetic phenylurea derivatives [N-(2-chloro-4-pyridyl)-N' ${ }^{\prime}$-phenylurea (CPPU) and TDZ] produce more hyperhydric shoots than adenine derivatives (BA and kinetin). But in anchote, hyperhydrated shoots appeared on media supplemented with BAP and kinetin but not on TDZ media (Kahia et al., 2016). Therefore, exogenous cytokinin type and concentration suitable for shoot regeneration may depend on plant species.

In additional works, the role of endogenous cytokinins in hyperhydricity was investigated (Ivanova et al., 2006). It was found that total cytokinin content in the tissues of hyperhydric shoots was higher than that of normal shoots grown on the same medium (Ivanova et al., 2006). Moreover, the application of exogenous cytokinins led to an overall increase in total cytokinin contents (Ivanova et al., 2006), suggesting that the action of exogenous cytokinins in hyperhydricity induction was at least partially due to upregulation of endogenous cytokinins levels (Ivanova et al., 2006). However, there might be exceptions. Some normal shoots with the same or higher levels of cytokinins compared with that of hyperhydric shoots did not show any hyperhydricity, indicating that endogenous level of cytokinins cannot be sufficient to induce hyperhydricity (Ivanova et al., 2006).

Rooting and acclimatization. The effects of different concentrations of IAA, IBA, and NAA on rooting of $H$. villosa 'Caramel' are shown in Table 2 and Fig. 2A. On media containing IAA, the highest rooting frequency was $56 \%$, whereas on media containing IBA, the highest rooting frequency was $62 \%$. The highest rooting rate $(95 \%)$ was obtained on medium containing $0.2 \mathrm{mg} \cdot \mathrm{L}^{-1}$ NAA, which was then used as medium for rooting. Another report on H. sanguinea 'Red Spangles' suggested that $95 \%$ shoots rooted on media containing 4.9 $\mu \mathrm{M}$ IBA (Hosoki and Kajino, 2003), indicating that auxin type and concentration suitable for rooting of shoots may depend on plant species. In the subsequent acclimation experiments, about $85 \%$ of rooted plantlets survived and grew to maturity normally (Table 2; Fig. 2B).

\section{Conclusion}

In conclusion, an efficient propagation protocol for $H$. villosa 'Caramel' was established. BA proved to be beneficial to callus induction and shoot regeneration than TDZ but the regenerated shoots on medium with higher concentration of BA inclined to be hyperhydric. MS medium containing $0.01 \mathrm{mg} \cdot \mathrm{L}^{-1}$ NAA and $0.1 \mathrm{mg} \cdot \mathrm{L}^{-1} \mathrm{BA}$ was the most effective for shoot regeneration. Compared with IAA and IBA, NAA was the optimum for regenerated shoots rooting. The highest rooting rate $(95 \%)$ was obtained on $1 / 2$ MS basal medium with $0.2 \mathrm{mg} \cdot \mathrm{L}^{-1} \mathrm{NAA}$. Eighty-five percent of rooted plantlets survived and grew normally in the field after acclimatization in greenhouse. The protocol established in this investigation will facilitate future mass propagation of $H$. villosa 'Caramel'.

\section{Literature Cited}

Barakat, M.N. and H. El-Sammak. 2011. In vitro culture and plant regeneration from shoot tip and lateral bud explants of Gypsophila paniculata L. J. Med. Plant Res. 5:3351-3358.

Frick, H. 1991. Vitrification in vivo in Lemna minor and its maintenance by isopentenyl adenine. J. Plant Physiol. 137:502-504.

Hosoki, T. and E. Kajino. 2003. Shoot regeneration from petioles of coral bells (Herchera Sanguinea Engelm.) cultured in vitro, and subsequent planting and flowering ex vitro. In Vitro Cell. Dev. Biol. Plant 39:135-138.

Ivanova, M., O. Novák, M. Strnad, and J. Van Staden. 2006. Endogenous cytokinins in shoots of Aloe polyphylla cultured in vitro in relation to hyperhydricity, exogenous cytokinins and gelling agents. Plant Growth Regulat. 50:219230.

Kadota, M. and Y. Niimi. 2003. Effects of cytokinin types and their concentrations on shoot proliferation and hyperhydricity in in vitro pear cultivar shoots. Plant Cell Tiss. Org. Cult. 72:261-265.

Kahia, J., P. Njenga, and M. Kirika. 2016. Improved micropropagation of plantlets from nodal explants of anchote (Coccinia abyssinica) -a calcium- and protein-rich tuber. HortScience 51:905-909.

Lane, W.D., H. Iketani, and T. Hayashi. 1998. Shoot regeneration fromcultured leaves of Japanese pear (Pyrus pyrifolia). Plant Cell Tiss. Org. Cult. 54:9-14.
Li, Z., X.F. Tan, Z.M. Liu, Q. Lin, L. Zhang, J. Yuan, Y.L. Zeng, and L.L. Wu. 2016. In vitro propagation of Camellia oleifera Abel. using hypocotyl, cotyledonary node, and radicle explants. HortScience 51:416-421.

Mazri, M.A. 2015. Role of cytokinins and physical state of the culture medium to improve in vitro shoot multiplication, rooting and acclimatization of date palm (Phoenix dactylifera $\mathrm{L}$.) $\mathrm{cv}$. Boufeggous. J. Plant Biochem. Biotechnol. 24 (3):268-275.

Miura, Y., T. Kitaura, R. Takayanagi, and T. Mitsuhori. 1995. Propagation of coral bells (Heuchera sanguinea Engelmann) by tissue culture, and forcing of flowering on the regenerated plants by a combination of low and high temperature treatment. Kanagawa Pref. Agr. Res. Sta. 136:17-24.

Murthy, B.N.S., S.J. Murch, and P.K. Saxena. 1998. Thidiazuron: A potential regulator of in vitro plant morphogenesis. In Vitro Cell. Dev. Biol. Plant 34:267-275.

Papafotiou, M. and A.N. Martini. 2016. In vitro seed and clonal propagation of the mediterranean aromatic and medicinal plant Teucrium capitatum. HortScience 51:403-411.

Picoli, E.A.T., W.C. Otoni, M.L. Figueira, S.M.B. Carolino, R.S. Almeida, E.A.M. Silva, C.R. Carvalho, and E.P.B. Fontes. 2001. Hyperhydricity in in vitro eggplant regenerated plants: Structural characteristics and involvement of BiP (Binding Protein). Plant Sci. 160:857-868.

Rout, G.R., A. Mohapatra, and S. Mohan Jain. 2006. Tissue culture of ornamental pot plant: A critical review. Biotechnol. Adv. 24:531-560.

Sen, A. and S. Alikamanoglu. 2013. Antioxidant enzyme activities, malondialdehyde, and total phenolic content of PEG-induced hyperhydric leaves in sugar beet tissue culture. In Vitro Cell. Dev. Biol. Plant 49:396-404.

Shen, X.L., W.S. Castle, and F.G. Gmitter. 2010. In vitro shoot proliferation and root induction of shoot tip explants from mature male plants of Casuarina cunninghamiana Miq. HortScience 45:797-800.

Stapfer, R.E. and C.W. Heuser. 1986. Rapid multiplication of Heuchera sanguinea Engelm. 'Rosamundi' propagated in vitro. HortScience 21:1043-1044.

Sujatha, M. and T.P. Reddy. 1998. Differential cytokinin effects on the stimulation of in vitro shoot proliferation from meristematic explants of castor (Ricinus communis L.). Plant Cell Rpt. 17:561-566.

Tabart, J., T. Franck, C. Kevers, and J. Dommes. 2015. Effect of polyamines and polyamine precursors on hyperhydricity in micropropagated apple shoots. Plant Cell Tiss. Org. Cult. 120:11-18

Tian, D.K., K.M. Tilt, F. Dane, F.M. Woods, and J.L. Sibley. 2010. Comparison of shoot induction ability of different explants in herbaceous peony (Paeonia lactiflora Pall.). Sci. Hort. 123:385-389

Van Staden, J., E. Zazimalova, and E.F. George. 2008. Plant growth regulators II: Cytokinins, their analogues and antagonists, p. 205-226. In: E.F. George, M.A. Hall, and G.J. De Klerk (eds.). Plant propagation by tissue culture. Vol. I: The background, 3rd ed. Springer, Dordrecht.

Vasudevan, R. and J. Van Staden. 2011. Cytokinin and explant types influence in vitro plant regeneration of Leopard Orchid (Ansellia africana Lindl.). Plant Cell Tiss. Org. Cult. 107:123-129.

Vinoth, A. and R. Ravindhran. 2015. Reduced hyperhydricity in watermelon shoot cultures using silver ions. In Vitro Cell. Dev. Biol. Plant 51:258-264. 